\title{
THE EFFECT OF CELEBRITY ENDORSEMENT AND BRAND IMAGE ON CONSUMER PURCHASES INTENTION ON MASPION PRODUCTS IN AMBON CITY
}

\author{
${ }^{1}$ Victor R. Pattipeilohy \\ ${ }^{2}$ Jean Rosalina Asthenu \\ ${ }^{3}$ Cynthia Imelda Tjokro \\ 1,2,3 Lecturer, Department of Business Administration, State Polytechnic of Ambon, Indonesia \\ victor.pattipeilohy@gmail.com
}

DOI: $10.31364 / \mathrm{SCIRJ} / \mathrm{v} 7.19 .2019 . P 0919698$

http://dx.doi.org/10.31364/SCIRJ/v7.i9.2019.P0919698

\begin{abstract}
The use of a public figure or an artist in advertising a product that is known by the term of celebrity endorsement and good brand image in the consumers' minds nowadays is consider very important to help companies in order to achieve their objectives. This research aims to examine to examine the effect of celebrity endorsement and product image to costumer purchase intention of Maspion products in Ambon City.

Samples of this research were 92 respondents who have ever watched the advertisement of Maspion product on television as well as buy and use the product. The instruments of research are the questionnaires using Likert scale. The data ware analyzed through the multiple regression technique.

The results show that the role of celebrity endorsement by the dimensions of expertise, trusts, attractiveness, and adds tagline on Maspion product is able to create the consumers purchases intention. Furthermore, the typical results is also found that good brand image of Maspion products in the consumer's mind is also able to create the consumers purchases intention.
\end{abstract}

Keywords: Celebrity Endorsements, Brand Image, Purchases intention

\section{Introduction}

The development of the marketing promotion strategy for a product that is getting high through various kinds of channels of communication both online and conventional method lead to the increasingly open attitudes of consumers to a variety of expressions and images both in magazines, newspaper, advertisement board, websites, radio, and television. Marketers will certainly try to get a small amount of time from a customer to inform him about the characteristics of products and brands that are good and unique (Malik and Qureshi, 2016). One potential strategy is to use a celebrity or public figure in an advertisement (Khan, et.,all. 2016, Rachbini, 2018). Marketing communications strategy by using an artist as an endorser of a brand or product is considered the most effective way to be able to increase the share of the market, the sales volume, as well as the consumers trust, with the belief that celebrities really represent their product (Malik and Qureshi, 2016).

The use of celebrity endorser should consider the level of popularity and character of celebrities who can represent the products, credibility, profession, expertise, trust, attractiveness (Amos et al., All in 2008, Priyankara , 2017) and also adds tagline that is one of the slogans or phrases made by the advertisers for a celebrity in the verbal form of a brand product that can motivate customers to buy it. The use of celebrity endorsement is expected to create consumers purchases intentions have an impact on the increase in the volume of sales and profit of the company (Simak, et., all. 2017, Adam and Hussein, 2017).

Brand image is one of the most valuable assets of the company, because it can form positive perception of consumer to buy the product (Arifin and Fachrodji, 2015). The brand can function as a source of product identification and carry the image of a company so that it can be used as a marketing strategy to win the competition (Mambu, 2015, Arista and Triastuti, 2011, Ambarwati, et., all. 2015)

The positive brand image of a product would make consumers like the products as well as strengthening the company image than the others competitors (Rahmi and Nizam, 2017). Consumers tend to buy products with positive brand image or due to the products are famous (Wijaya, 2013, Arslan and Zaman, 2014). Positive brand image is an important source to establish superiority differentiation in the enterprise and can be developed by using media, such as advertising (Chi, et.,all. 2016, Arslan and Zaman, 2014). Therefore, the good brand image can increase customer interest (Samuel and Lianto, 2014).

Intent to purchase is usually associated purchase behavior of which is the point of the key for consumers to access and evaluate the product and are used to measure the demand of consumers (Mirabi, et.,all. 2015, Morwitz, 2012). Intention to 
buy is influenced by various factors such as the price of the product, design, packaging, knowledge of the product, the quality, the support of celebrities, fashion (Shafiq et.,all. 2011). Intention of purchase as a possibility for consumers to buy a product (Chen et., all. 2012). So that the conditions of competition are high, the producer puts many attentions to the customers purchases intention in order to maintain the reputation to fulfill the need of the customers (Younus et., all. 2015).

Research that is done by Rachbini (2018) find that, the dimensions of celebrity endorsements such as attractiveness, confidence, and expertise of a celebrity proven to affect the customers purchases intention. The same result is also found by Younus, et.,all. (2015) that Celebrity endorsement is able to influence the customers purchases intention due the artist can influence the minds of consumers about the feasibility and reliability of the product. Conversely, a different findings form Stephanie, et.,all. (2013) states that the celebrity endorser which consists of attractiveness, trust, and the celebrity expertise can't affect the customers purchases intention.

Research from Arslan and Zaman (2014) found that a good or positive product image will increase consumer purchase intentions. Findings from Samuel and Lianto (2014) states that a product with a brand that is good then the customers tend to repeat purchase the brand. But the different result is found from the study that is conducted by Arista and Triastuti (2011) which states that the image of the brand can't affect consumer purchase intentions due to they don't see products have the good image, they tend to trust other consumer that use other product.

Maspion is a brand of products equipment home household and electronics are well-known and original made in Indonesia. The marketing are of the products is not only in a national scale but it also sold to several countries, especially in Southeast Asia. Growth in sales is a national of a product is on average $30 \%$ per year (Jawapos.com, 2017). One of the strategies of communication marketing that is used by manufacturers of products this is through advertising by using famous seniors artist of Indonesia with the tagline "Love products are made in Indonesia". Furthermore, the brand products Maspion is very good in the eyes of consumers because the products are produced in good quality and the prices are affordable so highly favored by consumers.

Based on the explanation of the phenomenon of celebrity endorsement, the brand image, and consumer purchase intentions as well as the results of several previous studies, the research aims to examine and analyze the influence of celebrity endorsement, brand image to the consumer purchase intentions on Maspion in City Ambon.

\section{Literature Review}

\subsection{Celebrity Endorsement}

The use of celebrities, with the goal to increase sales and / or the value of a brand, called celebrity endorsements (Priyankara, 2017). Nowdays, the manufacturer believes that celebrities are representative of the very influential to their brand, so they are willing to expend a lot of money to hire a celebrity as a brand endorser every year with the hope that the brand or product get special attention from the costumers (Malik and Qureshi, 2016). From the perspective of consumers, they want to have a brand with a reputation that is well in the market and then when a manufacturer involves a celebrity, things were becoming increasingly attractive because consumers feel that by using a brand that consumers will get some advantage because the products are supported by celebrities satisfying the desire to enjoy a brand that is equipped with a symbol of status (Adam and Hussein, 2017) because celebrity endorsers are used in advertising in general are famous such as in television, movie actor, popular athlete, and the other famous figure (Christian and Ariyanti , 2017).

The use of Celebrity endorsers in advertisements with the messages they bring tends to be easily trusted by consumers because it can form opinions, beliefs and experiences so that they can influence consumers and consumers' purchase intentions towards products (Christian and Ariyanti, 2017, Stephanie et., all. 2013). Measurement of celebrity endorsement that proposed by Gupta (2015), namely the power attractiveness, trust, expertise, and renewed by researchers with the added dimension of the tagline is the phrase verbal aims to influence consumers to buy the product.

Gunawan and Dharmayanti (2014) stated that with the use of celebrities as endorsers on an ad is getting increasing interest to buy someone, subsequent findings Rachbini (2018) states that celebrity endorsements play a role which is important in influencing the intention to buy the consumer through the power attractiveness, confidence, and expertise which is owned by celebrities. Based on the previous findings, the formulated hypothesis is:

H1. Celebrity endorsement has a positive and significant effect on the customers purchases intention on Maspion products in Ambon City.

\section{2 Brand Image}

Brand image is an important signal during the consumer purchasing decision making process, because consumers are more likely to buy products or well- known brands that have a positive brand image (Wang and Tsai, 2014). The image of the brand is the association of consumers to a brand that exist in their minds, the subjectively reflection of consumers to the brand, including a set of attributes of the brand that is different from the other (Chi et., all. 2016).

The brand image is very important in choosing a product or service that is offered by the company as to have the image of a brand that is easily recognized by consumers or brands that have been well-known, consumers can rely on the products or services of the ( Rahmi and Nizam, 2017). Consumers will buy a brand that has good image, so an increase in brand image will increase consumer purchase intentions (Arslan and Zaman, 2014). The brand image variables according to Bramantya and Jantra (2017) are price, packaging, product, function, image.

A study from Mambu (2015) states that it is very good for a company to improve its brand image because it has a significant influence on consumer purchase intentions. Moreover, the findings of Kwandy (2017) states that the image of the brand has the effect that positive toward intentions of purchase, by that reason the company should still provide a product that is quality so that the image of the brand they are amplified and can be focused to consumer target. Based on some previous findings, hypothesis that is proposed is:

H2. Brand Image has a positive and significant effect on the customers purchases intention of Maspion products in Ambon City. 


\subsection{Purchase Intentions}

Intent to purchase is an important concept that is very crucial in the study of marketing and the concept of principal in research in the field of marketing (Arslan and Zaman, 2014). Purchase intention refers to the intensity of the consumer's desire to buy a product or service. Purchase intentions are subjective psychological feelings that form in the minds of consumers (Chi, et., all. 2016). Furthermore, purchase intention is the preference of consumers to buy products or services. In other words, purchase intention has another aspect, namely consumers will buy products after evaluation (Younes, 2015). By because it is, marketers require a strategy that obviously that is based on an understanding full of the reasons which encourage consumers who intend to buy a product (Mirabi et.,all. 2015).

Intention to buy in general is a plan to conduct a purchase that is based on the interest of consumers to consume a product (Christian and Ariyanti, 2017), and the behavior of consumers who indicate the extent to which the commitment to carry out the purchase. Purchase intention is a tendency for someone to feel attracted to a particular object, which is a person's behavior related to decisions towards the direction of purchase and stimulated by certain factors (Idraswari and Pramudana, 2014). Indicator intention of buying by Rachbini, (2018) can be measured by want to know the product, interest to try, the consideration for the purchase, and will have to have the product.

\section{4 Conceptual Research Models}

The conceptual research methods in this study, based on the previous relevant studies can be described as follows:

Figure 1

Conceptual Research Model

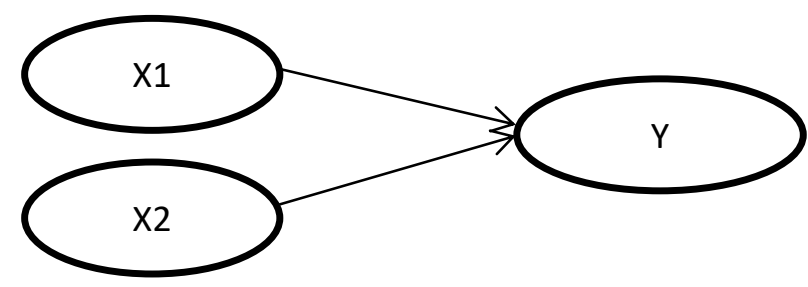

Note:

X1: Celebrity Endorsement

$\mathrm{X} 2$ : Brand Image

$\mathrm{Y}:$ Purchase Intention

\section{Research Methodology}

This research is explanatory. Methods of collection of data through interviews and questionnaires, using purposive sampling with the number of respondents as many as 98 respondent occupants of one specific area of housing in Ambon city, Indonesia. Variables were tested in the research this are Celebrity Endorsement and Brand image as a independent variable and dependent variable is Intention Purchase, which was measured by using a scale of Likert 5 points with interpretation very not agree to the highly agree (Younus, 2015).

The questionnaire instrument test method uses the validity test with the Pearson product moment formula and the correlation value > 0. 5 (Gunawan and Dharmayanti, 2014) and the reliability test uses alpha cronbach with a coefficient value $>0.6$ (Anggi and Soesanto, 2016).
The classic assumption test consists of tests of normality, multicollinearity, and heterokedasticity (Bramantya and Jatra, 2017). Mechanical analysis of the data using analysis multiple regression (Mubarok, 2016). To test the hypothesis of research is partially carried out by way of comparing the results of the $t$ test table with $t$ count, with the level of significance was 5\%.

\section{Results and Discussion}

The validity test of the questionnaire showed that overall the items on the variable celebrity endorsement, the brand image, and the intention of purchase is valid, with the value of the average correlation Pearson product moment is more substantial than 0.5 in the value of the item lowest was 0.583 and the highest was 0.846 . Furthermore, the reliability test of the three variables indicate the value of the coefficient Cronbach alpha in above 0.6 with the the lowest score in the variable brand image is 0.797 , intention to Purchase for 0.836 and the highest score of 0.935 is found on a variable celebrity endorsement.

The descriptive statistics towards the answers of respondents is as follows, for variable celebrity endorseme, the average score is 4.10 or agree, to the variable brand image the average score is 4.05 or agree, and variable intention of buying has the average score on 4.04 or agree.

The classical assumptions test of to assess the normality of the data is basically can be figured out by seeing the spread of the data graph normal plot, where in this research the data spread around the diagonal line and follow the direction of the diagonal line to meet the assumptions of normality or the data were normally distributed as can be seen in Figure 2 as follow:

Figure 2

Data Normality Testing Result

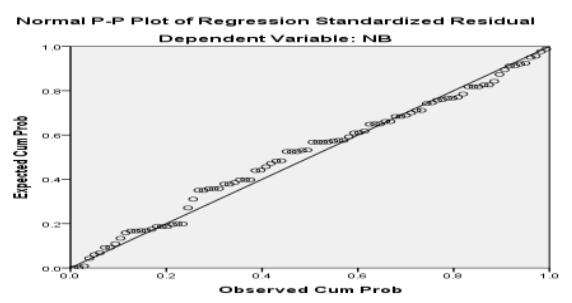

Source: Primary data processed (2019)

The result of Multicollinearity data test showed that the value of Tolerance does not exceed of 1 and the value of Variance Inflation Factor (VIF) doesn't exceed 10. Therefore, it can be concluded that there is no symptoms of Multicollinearity between variables independent of Products Innovation and the Competitive Advantage. For more details can be seen in Table 1 below:

Table 1

Multicollinearity Testing Results

\begin{tabular}{|l|c|c|}
\hline \multirow{2}{*}{ Model } & \multicolumn{2}{|c|}{ Collinearity Statistics } \\
\cline { 2 - 3 } & Tolerance & VIF \\
\hline $\begin{array}{l}\text { Celebrity } \\
\text { Endorsement }\end{array}$ & 0.523 & 3.957 \\
\hline Brand Image & 0.523 & 3.957 \\
\hline
\end{tabular}

Source: Primary data processed (2019) 
The result of heterokedasticity testing can be seen in scatterplot Chart in the following figure:

Figure 3

Heterokedasticity Testing Result

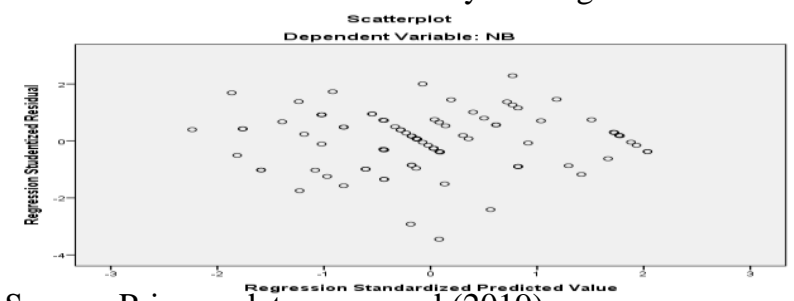

Source: Primary data processed (2019)

Figure 3 above shows that the data in the study is limited from of symptoms heterocedastity, due to the pattern of spread of dots of data above and is below the number 0 on the axis Y.

The statistic test by using multiple regressions to determine the magnitude of the effect of variable celebrity endorsements and brand image toward the intention of consumer purchasing can be seen in Table 2 as presented below:

Table 2

Multiple Regression Result

\begin{tabular}{|c|c|c|c|c|}
\hline Variable & $\begin{array}{l}\text { Un } \\
\text { Stdandardized } \\
\text { Coeficient }\end{array}$ & count & Sig & Note \\
\hline Constant & 2.082 & & & \\
\hline \begin{tabular}{|l|} 
Celebrity \\
Endorsement
\end{tabular} & 0.101 & 3.845 & $\begin{array}{r}0.00 \\
0\end{array}$ & Sig \\
\hline Brand Image & 0.557 & 6.530 & $\begin{array}{r}0.00 \\
0 \\
\end{array}$ & Sig \\
\hline R Square & 0.815 & & & \\
\hline $\begin{array}{ll}\text { Adjusted } & \mathrm{R} \\
\text { Square } & \end{array}$ & 0.811 & & & \\
\hline t Table & 1.983 & & & \\
\hline
\end{tabular}

Source: Primary data processed (2019)

Form the table 2 above, it can be explained that there is a positive and significant influence on variable celebrity endorsements to the intention of purchasing. It is seen from the results of testing on the magnitude of the $t$ count $=3,845>t$ table $=1,983$, with the coefficient regression is 0.101 , with the level of significance of 0.000 is less than 0:05 or 5\%. This results indicate that Hypothesis 1 (H1) is accepted.

The findings have proved that the Celebrity Endorsement influenced by the role of famous artist has given trust to the consumer for making the advertisement as a reference for shopping and is supported by the attractive appearance of the endorser, then create Purchase Intentions which reflected a sense of consumer interest to try the product after seeing the advertisement. The results is also supported by research from Younus et al., All (2015) which states that the use of the artist or celebrity to advertise the products from the company is able to influence the intention of buying from a consumer, because when a celebrity who has been familiar or synonymous with a product enhance the feasibility and the reliability of these products in the minds of consumers.

Moreover, the results of the statistic test to test the effect of the brand image to the intention of purchasing was found that the two variables have had the effect of which is positive and significant. It is evidenced in the amount of the $t$ count $=6,530>$ $\mathrm{t}$ table $=1,983$ with the value of the coefficient of the regression is 0.557 , with the level of significance of 0.000 is less than 0:05 or 5\%. The results of this test indicate that Hypothesis $2(\mathbf{H 2})$ is accepted.

The findings have proved that brand image which is formed of the function and usability of products that conform to the needs of consumers as well as the good quality and product design can create the intention of the consumers who are interested to try the product. The result is supported by the findings of Kwandy (2017) that good brand image is capable of creating the customer purchasing intention. Companies must be able to maintain positive brand image by always providing qualified products thus the brand image will be getting stronger and becoming the attention of target consumers.

\section{Conclusion}

The conclusions of this study are:

1. Celebrity endorsement which is indicated by the dimensions of trust, especially the role of endorser who is able to convince consumers to make advertisements as a reference for shopping and the dimensions of attractiveness which is mainly on attractive looks from the artist when delivering the advertisements is able to create consumers purchases intention.

2. Brand image is indicated on the functionality and usability of products that conform to the needs of consumers as well as qualified products and has interesting design is able to create consumers purchases intention.

The suggestions that can be formulated are:

1. Use of Celebrity Endorsement by the manufacturer should pay attention to the dimensions of trust especially the honesty of the artist in conveying a message in and advertisement as well as pay attention to the dimensions of expertise an artist to able to increase the trust of consumers at the time of conveying a message in the advertisements .

2. Producer of the product should have efforts to maintain and improve brand image of the product by fixing the packaging that can facilitate the use and storage of the product as well as set a price that is more economical that is able to reach by the consumers in general.

\section{References}

Adam. M. A, Hussain. N. (2017). Impact of Celebrity Endorsement on Consumer Buying Behavior. British Journal of marketing Studies. Vol. 5, No.3, pp. 79-121.

Ambarwati. M, Sunarti. Mawardi. M. K. (2015). Pengaruh Citra Merek Terhadap Minat Beli (Survei Pada Mahasiswa Universitas Brawijaya yang Menggunakan Pasta Gigi Pepsodent). Jurnal Administrasi Bisnis (JAB) Vol.25. No.1 Agustus 2015.

Amos, C., Holmes, G., \& Strutton, D. (2008). Exploring the relationship between celebrity endorser effects and advertising effectiveness A quantitative synthesis of effect size. International Journal of Advertising. 27(2), pp. 209234.

Anggi. V. F, Soesanto. H. (2016). Analisis Pengaruh Daya Tarik Iklan Dan Selebriti Endorser Pada Promo Adaaqua Terhadap Minat Beli Amdk Merek Aqua Dengan Citra Merek Sebagai Variabel Intervening (Studi Kasus Pada Mahasiswa S1 Di Jawa Tengah Dan DIY). Diponegoro 
Journal Of Management, Vol.5, No.3, Tahun 2016, Hal. 114. ISSN (online):2337-3792.

Arifin. E, Fachrodji. A. (2015). Pengaruh Persepsi Kualitas Produk, Citra Mrek dan Promosi Terhadap Minat Beli Konsumen Ban Achilles di Jakarta Selatan.Jurnal MIX, Vol.V, No. 1.

Arista. E. D, Triatuti. S. R. (2011). Analisa Pengaruh Iklan, Kepercayaan Merek, dan Citra Merek Terhadap Minat Beli Konsumen. Aset, Vol. 13, No.1, ISSN: 1693-928X, Maret 2011.

Arslan. M, Zaman. R. (2014). Impact of Brand Image and Service Quality on Consumer Purchase Intention: A Study of Retail Store in Pakistan. Research on Humanities and Social Science. Vol.4, No.22, 2014. ISSN (Paper)22245766 ISNN (online)2225-0484.

Bramantya. Y. B, Jatra. M. (2016). Pengaruh Celebrity Endorser dan Brand Image Terhadap Keputusan Pembelian Yamaha Jupiter MX di Kota Denpasar. EJurnal Manajemen Unud, Vol. 5, No.3, 1745-1771, ISSN: 2302-8912.

Chen, C. C., Chen, P.K., dan Huang, C. E. (2012). Brand and Consumer Behavior. Social Behavior and Personality, Vol. 40 No. 1, pp. 105-114.

Chi. Y. Q, Zhu. J. L. Yan. Z. J. (2016). A Study on the Influence of Brand Image on Consumers' Purchase Intention-Based on IT Skills Training. 2016 Internationall Conference on Informatics, Management Engineering and Industrial Application (IMEIA 2016) ISSN: 978-1-60595345-8.

Christian. R, Ariyanti. M. (2017). Pengaruh Celebrity Endorser Terhadap Minat Pembelian Situs Belanja Online Tokopedia di Kota Bandung (Studi Kasus Pada Chelsea Islan Dalam Iklan Tokopedia). e-Proceeding of Management: Vol.4, No.1 April 2017. ISSN: 2355.

Gunawan. F. A, Dharmayanti. D. (2014). Analisis Pengaruh Iklan Televisi dan Endorser terhadap Purchase Intention Pond's Men Dengan Brand Awareness Sebagai varriabel Intervening. Jurnal Manajemen Pemasaran Petra Vol.2, No.1, (2014) 1-14.

Gupta, R., N. Verma, D. (2015). Impact of Celebrity Endorsement on Consumers Purchase Intention: A Study of Indian Consumers. Australian Journal of Business and Management Research. Vol.05 No.03. July-2015.

Indraswari. N. M, Pramudana. K. A. S, (2014). Pengaruh Kredibilitas Celebrity Endorser Dan Kewajaran Harga Terhadap Niat Beli Konsumen Wanita Pada Online Shop Produk Pakaian. E-Jurnal Manajemen. Vol.3, No.4 (2014).

Khan. S. K, Ruksar. A, Shoaib. M. (2016). Influence of Celebrity Endorsement on Consumer Purchase Intention. IOSR Journal of Business and Management (IOSR-JBM). E-ISSN: 2278-487X, p-ISSN: 2319-7668. Vol. 18, Issue I. Ver. I. PP06-09.

Kwandy. C. P. (2017). Effect of Brand Image and Price Towards Purchase Intention in Beef-Jerky Company. Review of Management And Enterpreneurship, Vol.01/No.01/2017.

Mambu. E. (2015). The Influence of Brand Image, And Service Quality Toward Consumer Purchase Intention of
Blue Bird Taxi Manado. Jurnal EMBA, Vol.3, No.4 Desember 2015, Hal. 645-653, ISSN: 2303-1174

Malik. H. M, Qureshi (2016). The Impact of Celebrity Endorsement on Buying Behavior. Journal of Marketing and Consumer Research. ISSN 2422-8451An International Peer-reviewed Journal Vol. 26. 2016.

Mirabi. V, Akbariyeh. H, Tahmasebifard. H. (2015). A Study of Factors Affecting on Customers Purchase Intention Case Study: The Agencies of Bono Brand Tile in Tehran. Journal of Multidisciplinary Engineering Science and Technology (JMEST) Vol. 2, Issue 1, ISSN:3159-0040. January-2015.

Morwitz. V, (2012). Consumers' Purchase Intentions and Their Behavior. NOW the essence of knowledge, BostonDelft. Foundation and Trends in Marketing.

Mubarok. D. A. (2016). Pengaruh Celebrity Endorsement Terhadap Minat Beli Konsumen (Studi pada Konsumen Mahasiswa Kelas Reguler Sore STIE INABA Bandung). Jurnal Indonesia Membangun, Vol.3, No.1, ISSN: 14126907.

Priyankara. R, Weerasiri. S, Dissanayaka. R, Jinadasa. M. (2017). Celebrity Endorsement and Consumer Buying Intention with Relation to The Television Advertisement for Perfumes. Management Studies, Vol. 5, No. 2, 128-148, doi: 10.17265/2328-2185/2017.02.05.

Rachbini. W. (2018). The Influence of Celebrity Endorsement on Purchase Intention (A Study on VIVO V7). IOSR Journal of Business and Management (IOSR-JBM). EISSN: 2278-487X, p-ISSN: 2319-7668. Vol. 20, Issue 8. Ver. Iv. PP 59-66.

Rahmi. D, Nizam. A. (2017). Pengaruh Citra Merek Terhadap Niat Pembelian Tiket Pesawat Secara Online Pada Konsumen Traveloka.Com dengan Kepercayaan Sebagai Variabel Mediasi. Jurnal Ilmiah Mahasiswa Ekonomi Manajemen, Vol2, No.3, Agustus 2017: 70-85.

Semuel. H, Lianto, S. L. (2014). Analisis eWom, Brand Image, Brand Trust Dan Minat Beli Produk Smartphone Di Surabaya. Jurnal Manajemen Pemasaran, Vol.8, No.2, ISSN 1907-235X, Oktober 2014.

Shafiq, R. Raza. I, Z. U. Rehman. M. (2011). Analysis of the factors affecting customers purchase intention: The mediating role of perceived value. African Journal of Business Management Vol. 5(26), pp. 10577-10585.

Simak. A. H, Saerang. I. S, Jan. A. B. H. (2017).Pengaruh Celebrity Endorser dan Iklan Televisi Terhadap Minat Beli Sepeda Motor Yamaha (Study pada Mahasiswa Fakultas Ekonomi dan Bisnis Universitas Sam Ratulangi Manado). Jurnal EMBA. Vol. 5, No.2. Hal. 2377-2384.

Stephanie. E, Rumambi. L. J, Kunto. Y. S. (2013). Analisa Pengaruh Rio Dewanto Dan Donita Sebagai Celebrity Endorser Terhadap Minat Beli Produk Axe Anarchy Dengan Daya Tarik Iklan Dan Efek Iklan Sebagai Variabel Intervening. Jurnal Manajemen Pemasaran. Vol.1, No.2 (2013) 1-9.

Wang. Y. H, Tsai. C. F. (2014). The Relationship Between Brand Image And Purchase Intention: Evidence From Award Winning Mutual Funds. The International Journal of Business and Finance Research, Vol.8, No.2. 
Wijaya. I. M. (2013). The Influence of Brand Image, Brand Personality and Brand Awareness on Consumer Purchase Intention Of Apple Smartphone. Jurnal EMBA, Vol. 1, No.4 Desember 2013. Hal. 1562-1570.

Younus. S, Rashhed. F, Zia. A. (2015). Identifying the Factors Affecting Customer Purchase Intention. Global Journal of Management and Business Research: A Administration And Management, Vol. 12, Issue 2 Versioan 1.0. Online ISSN: 2249-4588\& Print ISSN: 0975-5853.

https://www.jawapos.com/ekonomi/bisnis/23/01/2017/maspio n-perkuat-pasar-domestik/ 